\title{
Independence and the Creation of Nation-States in Iberian America: A Comparative Analysis of Portuguese and Spanish America
}

\author{
MARCO A. PAMPLONA
}

The process of nation-state building in Latin America was certainly not even; it took longer in some cases than in others; and the creation of new republics was far from being a generalized phenomenon, let alone a swift one. In the Americas, it can be said that only the United States constituted an exception, bringing the experiment of the modern republic into the world at the very first fracture of the Ancien Régime. Moreover, the American Revolution opened the way for both France and Haiti to also accelerate their own internal processes and move to the peak of the so-called Age of Revolutions. Nevertheless, even in the example of the early American republic, the structures of the modern nation-state would only be fully realized much later, in the second half of the nineteenth century. It was only in the aftermath of the Civil War, especially during the two decades following Reconstruction, that more Hamiltonian-like or centralized policies took place in America, promoted by a de facto national state project. ${ }^{1}$ Conversely, in the case of Iberian America, what could be perceived throughout the first half of the nineteenth century was a series of long-term political changes, initially triggered by the fall of the Spanish Empire and followed by decades of revolutions and wars of independence. Attempts at nation building took different directions among the various parts of the former Iberian empires, and the political map of the continent changed many times over during the post-revolutionary period. Liberalism and republicanism wrought many important changes to the principles of legitimization of political power, ${ }^{2}$ but there was no single republican model for Iberian American countries. The label of Republicanism itself applied at the time to a great variety of endeavours, some radical, others not, which brought about the development of many new political practices. Such practices certainly created modifications in the relationships between the 'many and the few' and, at the same time, extended and redefined the old borders of inclusion and exclusion for the new emergent polities. Class, ethnic, racial, and gender cleavages all need 
to be considered from this perspective, and the different connections these groups were to establish with the building of citizenship under the new order must be highlighted for each of the different societies under study. In short, diversity was what prevailed as 'the' pattern.

A second important factor to emphasise is the importance of analysing state building and nation-formation as two intertwined processes. The experience appears very different depending on the Iberian America societies under examination. In cases where the legal and coercive capacity of the previous colonial state and its professional bureaucracies did not begin to disintegrate immediately, let alone vanish, elements of continuity with the past remained for a far more extended period. The provinces of the Peruvian highlands are a good example of such a tendency. In these areas, the previous social and political agents did succeed in setting up a great deal of the framework within which the development of new political coalitions and proposals was to take place. Conversely, there were other cases in which the control of the administration of the colonial period became more fragmented (as, for example, in the late eighteenth-century Viceroyalty of La Plata), and hasty changes and anticipations of separatist efforts predominated from 1810 onwards. By the same token, however, a much longer period of ensuing political instability predominated in such regions. ${ }^{3}$

Thirdly and finally, some brief comment is necessary in order not to fall into anachronistic comparisons - that is, into those comparisons which, according to some present theoretical models, may erroneously suggest linear developments that did not exist as actual options for the decision-makers and actors of the time - and, therefore, in order to avoid further generalizations about the continent which might lead to misleading conclusions. For this reason, it is important to underline a few fundamental historical differences that will help us to refrain, from the outset, from any superficial comparisons between the United States state-building process and the Latin American ones.

In addition to the pioneering example set, as we have already mentioned, by the American Revolution, it is important to note that men and women at the time responded to the very specific conjuncture of late eighteenthcentury British politics, in the aftermath of the Seven Year War. This means that the representations, values, ideas and concepts at play in their political discourses and actions were simultaneously both the product and the response to this specific political conjuncture and its challenges. ${ }^{4}$ Furthermore, the US process of nation-building began with the independence of already constituted polities in the British colonies. These existing polities were to remain as such - that is, a grouping of provincial authorities in a loose confederation, mostly dominated by leading Southern elite men and planters with a rhetoric of state-rights - until the mid-nineteenth century. ${ }^{5}$ 
Belonging to a totally new chronology, the Iberian American processes of nation-state building shared very different experiences. These Iberian societies had benefited already from the examples of the French and Haitian Revolutions, and they all stemmed from the unexpected and profound crisis that hit the Iberian world and, more dramatically, the Spanish Crown itself, in the first decade of the nineteenth century. It can be said that it was Napoleon's invasion of the Iberian Peninsula that immediately opened a phase of intense political experimentation for the Iberian empires on both sides of the Atlantic. Throughout the vast network of territories ruled by the Spanish Crown, new coalitions came into being and local political sovereignty was demanded. In this new space of experimentation, symbolized by the Age of Revolutions and characterized as modern, new concepts, new words, and new projects were created and disseminated in an attempt to make sense of the situation experienced by all at the time. ${ }^{6}$ Contemporary politicians and leaders needed to confer some meaning on the ongoing changes, and the Cadiz debates regarding the enactment of a constitution in all the Spanish territories would open up a totally new set of expectations in this Age of Revolutions. The new constitutional charter expressed an in-depth reconsideration of the relations between sovereignty and traditional powers that existed everywhere. Hispanics in the Americas and in the Peninsula debated among themselves the meaning and concepts of sovereignty and representation, the idea of nation and the need to subject the monarchy to a new constitution. Their shared feelings helped in the creation of a new political vocabulary and this resulted in the construction of a new modernity, one which was to become characteristic of the entire Atlantic world and which would be translated into ideas, attitudes, and unforeseen political practices in both colonial and metropolitan societies.

During the doceañismo (the period of liberal changes initiated in Spain after 1812), the many ideas put forward by the legislative representatives who proclaimed the Spanish Constitution of 1812 were to profoundly influence the Hispanic world as a whole. The Cadiz Constitution of 1812 became both an American and a Spanish document, a charter taken up on both sides of the Atlantic. Some of the liberal reforms it enacted (initially conceived for the Peninsula), such as the creation of committees or provincial delegations, or of ayuntamientos (town councils) in the small cities ended up having a more profound and unforeseen impact when applied to the New World. There, they helped free the important local powers of many medium-sized towns and villages from the influence of the big cities, the usual major colonial administrative and political centres of the viceroyalties of the past.

In addition to this, the Cadiz Charter provided for the complete abolition of the institutions of the nobility, of the Inquisition, and of the tribute paid by Indian communities and forced labour - such as the mita in the Andean 
region and the individual serfdom that was still endured by many in the Iberian Peninsula. It also sanctioned the creation of a unitary state with equal laws to be applied in all parts of the Spanish empire; it substantially restricted the king's authority and entrusted ultimate authority to the Courts. By granting the vote to all males except those of African descent, and not stipulating any wealth or literacy criteria, the Constitution of 1812 was highly advanced for its time. Indeed, it far surpassed the constitutions of the other representative governments of the period - those of Great Britain, United States and France - especially concerning the extension of political rights to the vast majority of the adult male population.

These two procedures - that is, the enlargement of the electorate and the enhancement of their political activities - combined with the establishment of a three-tier representative government - the municipality, the province, and the monarchy - enabled villages of over a thousand inhabitants to form their own ayuntamientos. Thus, part of the power of the main centres was transferred to the many small localities, in which an increasing number of people began to harbour political aspirations of their own.

Notwithstanding this unparalleled expansion of political representation in Hispanic America, civil wars broke out in the following years. Groups that insisted on the formation of local juntas but refused to accept the new Spanish government competed against those other groups that chose to remain under the authority of the Spanish legislature and stayed loyal to the Regency. Political cleavages among the members of the ruling elites combined with their mutual regional antipathies and with the social tensions they usually experienced, exacerbating the endless conflicts that frequently sprung up over the claim for local autonomy by introducing the element of political sovereignty.

There followed a wave of separatist movements that ended only with the collapse of the Spanish colonial empire in the Americas. From 1810 to around 1830 - in less than three decades - nearly 17 new would-be nation-states emerged and replaced the four former viceroyalties and captaincies. And, in the midst of this warfare for independence, top down solutions evolved in the different provinces, sequenced differently in each case. Again, the experience of doceañismo constitutionalism and of liberalism did not develop evenly.

Roughly speaking, and for analytical purposes only, five main regions can be distinguished in Hispanic America, in view of their particular shared features. These are as follows: (i) New Spain and its surrounding area such as Guatemala, both marked, from the very beginning, by the spread of the constitutional debate over representation and autonomy to towns and villages; (ii) Venezuela and New Granada where militarization of the 
fight and political centralization predominated; ${ }^{8}$ (iii) the region of La Plata and Chile where the Constitution of 1812 had a lesser influence over the political debates and where military power was very much scattered through their hinterlands; ${ }^{9}$ (iv) Lima and the Peruvian highlands where the defeat of the royal forces and the liberation of the city of Lima resulted from the convergent actions of two distinct army movements, one initiated in the northernmost and the other in the southernmost part of the continent; ${ }^{10}$ and finally (v) Cuba, where local elites, who had benefited from the Haiti crisis, decided to welcome the boom of the sugar-cane plantations and the adjustment to large-scale chattel slavery, and therefore fiercely opposed the liberalism of the Cadiz Constitution. ${ }^{11}$

There is an important distinction to be made in relation to the timing of independence in Brazil, vis-à-vis the Spanish American regions. I refer to the almost ten-year gap which separated the spread of liberal ideas and attitudes - mainly of constitutionalism, autonomy, and political sovereignty - in the Portuguese colony from the spread of these same ideas and attitudes at the time of the Spanish doceañismo. The Portuguese revolutions of Porto and Lisbon, which brought to power the Liberal legislative representatives who promulgated the Portuguese Constitution of 1822, were both linked to the so-called years of the 'vintismo' (1820s). In short, unlike the first liberal eruptions in the Peninsula which occurred during the early Spanish reaction to the Napoleonic invasions of 1807-1815, these late liberal protests and ideas, which mushroomed in Portugal in the 1820 s, belonged to a conjuncture which led to new political demands. What was at stake here was not the defence of the kingdom's territorial integrity by its peoples due to a profound crisis experienced by the Crown. Rather, in Portugal, liberalism developed as an opposition to and a solution for the revival of absolutist tendencies foreseen with the coming to the throne of King João VI (in 1818), after the death of his mother, Queen Maria. So, in a Spain under attack from the French, liberalism and constitutionalism represented mots d'ordre associated with loyalty to the captive King, and, at the same time, in support of the autonomy achieved by some provinces and towns amid the ongoing war. In Portugal, however, constitutionalism was but a reaction against the fear of renewed absolutism brought about by the return of a King who had remained safely distant in Brazil during the whole period of the Peninsular War.

As had happened with Spain, the Napoleonic invasion of the Iberian Peninsula had drastically changed the destiny of the Portuguese empire overseas. And, if the flight of the Portuguese royal family and court to Brazil at the end of 1807 , well escorted by the British warships, did help save the crown, it also initiated a totally new phase in the life of the colony, a phase which I will now examine in more detail. 
The first huge transformation occurred with the city of Rio de Janeiro which became the seat of the Portuguese empire. In addition, the old colonial status of Brazil also underwent significant changes. To begin with, the opening of Brazilian ports to all 'friendly nations' in 1808 allowed the immediate presence of foreign merchants in the colony and Britain became the nation that benefited most from such new circumstances, with its products enjoying the lowest tariffs vis-à-vis the other competitors. ${ }^{12}$ The removal of the court to Brazil also demanded a new administrative structure of government for ruling the empire from Rio de Janeiro. The Prince Regent had to govern with the Ministry of War and Foreign Affairs, the Navy, the Ministry of Finance and of the Interior. He created the Banco do Brasil, the Junta Geral do Comércio and the Casa da Suplicação, or the Supreme Court. Throughout this period in Brazil, João VI promoted several expansionist campaigns with a view to annexing more territories to the north in 1808 , and to the south, such as Montevideo, in 1817, when Luso-Brazilian troops invaded the city and annexed the territory of Banda Oriental to the Province of Cisplatina. ${ }^{13}$

Nevertheless, neither the presence of the Crown, nor the patrolling of the British Navy could avoid the dissemination of French revolutionary ideas across the Atlantic. In 1817, the first republican insurrection sprang up in the north-east, in the city of Recife, quickly spreading to most surrounding villages of the province. The revolutionaries demanded independence from Portugal with the support of much of the city's population. Led by merchants and members of secret societies who professed the ideals of the French philosophers and loathed the North American republic, the rebels expelled the governor, seized power and established a provisional government. ${ }^{14}$

At the beginning, this revolutionary movement was very successful and easily spread to the adjoining hinterland areas of Rio Grande do Norte and Paraiba. It was quelled, however, in Ceará, and was brutally repressed in Bahia. Later, troops and ships were sent from both Salvador and Rio to blockade the port of Recife. In no more than a few months, the LusoBrazilian forces had put an end to this revolutionary republican experiment, and its main leaders were either executed or severely punished..$^{15}$

Meanwhile, the situation in Portugal had become more and more critical. The defeat of Napoleon in 1814 marked the end of the long period of wars, which had affected all of Europe. The withdrawal of the French left the Portuguese Kingdom extremely impoverished. Colonial commerce, the main source of wealth for Portuguese merchants in the past, had diminished significantly with the opening of the Brazilian ports to other European nations. Discontent grew and crowds were roused to support a movement that demanded the immediate return of the royal family to Lisbon. In 1820 , a liberal, constitutionalist revolution broke out in the city of Porto, and 
Lisbon soon followed suit. The Portuguese legislative assembly forced the return of the King and demanded that he swear obedience to the liberal constitution that was being drafted.

The following years saw the upsurge of movements in support of the Portuguese legislature in many places in Brazil as well, ousting old colonial governors and creating provisional government juntas. Representatives of the different provinces and kingdoms that constituted the Portuguese empire at the time (Portugal, Brazil, and Algarve) were sent to join the Portuguese government in Lisbon, where they would endorse the new constitution in an effort to curb the absolute powers of the monarch. As a result of the pressure of these movements, João VI returned to Portugal in 1821 and capitulated to Parliament. He left Brazil, however, in the hands of his son Pedro as the Prince Regent.

In sharp contrast with the revolutionary political liberalism applied by the Portuguese to domestic affairs were the legislature's views regarding the issue of the empire. Regarding this question, the Lisbon government simply requested the return of Brazil to its old colonial status, in order to overcome the commercial disadvantages suffered in the previous years. Many Portuguese merchants both in Portugal and in Brazil gave support to such intentions, and soon a widespread fear of 're-colonization' divided opinions and hastened new groupings of interests, either in favour of or against emancipation.

Tensions between the Portuguese courts and the Prince Regent in Brazil escalated during the following years. Among the important elite groupings or political factions that disputed the leadership and control of the power conflicts of the period were very different interests. The so-called 'Portuguese party', for instance, was formed by merchants with strong ties to the Portuguese monopolies, who backed the return to colonial status for this part of the empire and wanted Brazil returned to its pre-1808 situation. This grouping usually counted on the support of the Portuguese troops concentrated in Rio de Janeiro and stationed in port-cities in the north and south of Brazil. The members of this party might well be either constitutionalists and liberals, or stout supporters of the King's absolute power.

The 'Brazilian party' constituted a second large faction. It represented the interests of merchants and producers of staple crops and other goods, and those who wanted to continue accessing European consumers directly without the intermediation of the Portuguese. Among these men were many constitutionalists, who looked for autonomy within the Luso-Brazilian Empire, but this group also included those who were beginning to dream of separatism and of the creation of a fully independent state. This group had another thing in common: they also usually counted on the support of 
the many who had benefited from the presence of the Court in Brazil in the previous decades - that is, the Portuguese administrators who remained in the government of Brazil after the departure of the King, and a few important European financiers and merchants, mainly British and French.

Last but not least, there was still a range of popular and middle-class urban sectors to be considered. This motley group was comprised of small merchants, pharmacists, journalists, clergymen and employed freemen who, together with a minority of discontented landowners in the north-east, flirted with a so-called 'Radical-Liberal party' with republican overtones. Some of these popular forces believed independence could bring changes to better the standard of living of the bulk of the population.

The Portuguese legislature continued with its rhetoric of 're-colonization' and, by the end of 1821, they urged the return of Pedro, by then considered to be 'disobedient'. While strongly opposed on the one hand to the growing metropolitan pressure, most provincial elites, on the other hand, feared the eventual return of the republican uprisings that which, since the Pernambuco revolution of 1817, had been menacing their privileged status, privileges which they had consolidated over a long period of time based on the monarchical order and almost entirely supported by slavery.

In particular, the wealthiest elites of the axis of the south-east (which encompassed the provinces of Rio, São Paulo and Minas) and of its surrounding regions saw their autonomy was at stake, that their political importance was being restricted and was indeed at risk of vanishing in the short term. Members of both the 'Brazilian party' and the 'Portuguese party' greatly feared the potential consequences that the agitation of the lower classes (the homens do comum or 'commoners') could bring. Furthermore, the threatening shadow of the slave insurrection and revolution in Haiti still lingered, with its implication that events of a similar nature could also occur in Brazil. The mushrooming of the independence wars in the colonies of Spanish America simply brought to the fore what those ruling elites at the time feared most - the enlargement of the basis of political participation in the advent of an independent government.

The subject of a new social contract or of new liberties to be agreed upon was to become paramount, as the kingdom of Brazil made a move to become an autonomous political body. Among the main goals of the ruling elites was the maintenance of the monarchy and of the slave order. The Prince Regent viewed such an occasion as an excellent opportunity to disobey the Lisbon ultimatum, and deftly guided by José Bonifácio de Andrada e Silva, he rapidly proclaimed independence on 7 September 1822 . Once free from the Portuguese legislative assembly's constitutional attacks and constantly alert to the danger of 'anarchy' from below, the forging of the Brazilian nation-state began. A new Brazilian Empire was being planned: the name 
would remain the same - Brazil - and it would continue to be called the Brazilian Empire but it no longer referred to that parcel or portion of the Luso-Brazilian Empire. The new Brazilian Empire was to be conceived now as a whole in and of itself, an autonomous political entity formed by new gatherings of contiguous territorial tracts, mainly those controlled by earlier loose provincial powers that had previously belonged to Portuguese America. Some of these latter territories simply needed to be kept under control; others had gained a considerable degree of autonomy and would still need to be carefully convinced to obey the new government thereafter or be conquered by force.

As in Hispanic America, at least four distinct regions can be highlighted in Portuguese America regarding their different political reactions towards the early demands of the Luso-Brazilian authorities and the demands of the constitutional monarchy created by King Pedro after independence. These regions were (i) Grão Pará and Maranhão, the most northern provinces, more prone to side with the Lisbon government; (ii) Pernambuco and Bahia, the oldest and more populous north-eastern provinces, each with complex social structures of their own (both had flirted with republicanism and, though their experiences failed, the local elites were not going to easily give away their autonomy during the 1820s); (iii) São Paulo, Minas Gerais and Rio, the three south-eastern provinces which had been benefiting economically since the transmigration of the Portuguese Court to Brazil in 1808 and whose elites mostly sided with Pedro after 1822; and (iv) the newest province of São Pedro do Rio Grande, a convulsive frontier, sparsely populated by people of both Portuguese and Spanish descent, and still in dispute at the time of independence.

However, by the 1840s, all of the above regions had come under the control of the new Brazilian nation-state, now representing a new coalition of forces, and responsible for the building of state power and authority upon totally different bases to those which had existed previously. This now politically sovereign nation-state lasted, in the form of a constitutional monarchy, until $1889 .{ }^{16}$

The quelling of political turmoil in the more distant provinces in the aftermath of independence cost Pedro I dearly. Dissenting elites revolted in Pará (1822), Maranhão (1823), Bahia (1822-23) and Pernambuco (1824) and they had to be fought to the bitter end. Whether their demands implied the maintenance of the old political links with Portugal or whether they expressed attempts to create new radical republican orders, they were always viewed as seditious conspiracies and upheavals against the emperor that had to be quickly suppressed, since the sovereignty of this new monarchy was not to be endangered. However, notwithstanding the efforts of Pedro I in the tumultuous border of the southern province of Rio Grande, the so- 
called patriots of the Banda Oriental successfully defeated the Brazilian Empire's attempt to consolidate its authority in the region and declared the independence of their republic (the República Oriental del Uruguay) in 1828.

Rebellions seeking political autonomy, and even separatism, continued to erupt in different Brazilian provinces throughout the whole period of the Regencies (1831-1840). ${ }^{17}$ In the upper north, the revolts of Cabanagem (Pará, 1835-1840), Sabinada (Bahia, 1837-1838) and Balaiada (Maranhão, 18381840) are known examples of such protests. In all of them, the involvement of popular sectors was very intense, increasing the fear of anarchy among the elites. In addition to those, there was a new republican movement unleashed in the south. It was known as the Farroupilha Revolution (also dubbed the 'Guerra dos Farrapos' or 'Ragamuffin War'), a revolt which turned into a fierce ten-year war (1835-1845) until definitively quelled by the emperor's forces.

In short, the emperor's strength derived from his allies in the southeast, formed by the provincial elites of Rio de Janeiro and São Paulo and strengthened by the progressive support of Minas Gerais. It was from these nuclei the influence of Pedro I's court began to extend into the outer provinces. Such was not an easy task, as mentioned before, and the heyday of the empire can only be said to have arrived in the 1860s and early 1870s, during the reign of Pedro II (1831-1889). Peace or political stability was an outcome of the conservative regression that characterized the end of the Regencies period, led by the Saquarema group, which represented to a great extent the interests of the provincial elites of Rio de Janeiro. It followed a period of consolidation of established authorities, marked by a strong trend towards centralization and by the alternation in power of the two main political parties at the time - the Liberal Party and the Conservative Party. ${ }^{18}$ Such political games would last until the end of the Pedro II's, in 1889.

The massive campaigns of the monarch fighting against the insurgent provinces relied on local power elites and, in particular, on the help of the municipal councils or câmaras which played a crucial role in the consolidation of the emperor's central power. It was their negotiation of political authority that hastened the process of centralization, with practices that implied, in turn, the granting of concessions to their local allies, and establishment of a pact between modernity and tradition, between the new and the old.

1 See George M. Fredrickson, ed., A Nation Divided: Problems and Issues of the Civil War and Reconstruction. Minneapolis, 1975 and Eric Foner, Reconstruction: America's Unfinished Revolution, 1863-1877, New York, 1988. 


\section{Creation of Nation-States in Iberian America}

2 See Roberto Breña, El primer liberalismo español y los procesos de emancipación de América, 1808-1824, Mexico, 2006, on the influence of this Spanish liberalism. And, for a more specific approach of how Enlightenment ideas were absorbed and developed in the one of the viceroyalties, see José Carlos Chiaramonte, La Ilustración en el Rio de la Plata. Cultura eclesiástica y cultura laica durante el Virreinato, Buenos Aires, 2007.

3 This is what the term 'larga espera', coined long ago by Halperín Donghi, seems to suggest. It refers to the long road towards the institutionalization of the new powers in the La Plata region, for the interplay between state and nation to be considered more effectively.

4 See J. Greville and A. Pocock, 'Virtue and Commerce in the Eighteenth Century', Journal of Interdisciplinary History, 3 (1972), pp.119-34; Bernard Bailyn, The Ideological Origins of the American Revolution, New York, 1967; and Gordon S. Wood, The Creation of the American Republic, Chapel Hill, 1969.

5 See Jack P. Greene, The Intellectual Construction of America: Exceptionalism and Identity from 1492 to 1800, Chapel Hill, 1993; and Jack P. Greene, 'State and National Identities in the Era of the American Revolution' in D.H. Doyle and M.A. Pamplona, eds, Nationalism in the New World, Athens, 2006, pp.61-79.

6 An excellent debate on the crisis of the Atlantic empires can be found in José M. Portillo, Crisis atlántica. Autonomía e independencia en la crisis de la monarquía hispana, Madrid, 2006. For the links between history, experience, and modernity in Iberian America, see Guillermo Zermeño, La cultura moderna de la historia. Una aproximación teórica e historiográfica, Mexico, 2002.

7 See Revista de Indias, LXVIII, 242 (2008). In this special issue, edited by Mónica Quijada and Manuel Chust, several authors present studies on the repercussion of liberalism and the Cadiz Constitution in different regions of the Iberian world.

8 For the militarization of the political struggle in New Granada and Venezuela see the following articles: Häns Joachim König, 'Independência e nacionalismos em Nova Granada/Colômbia' and Inés Quintero, 'A independência da Venezuela, resultados políticos e sociais', both published in Marco A. Pamplona and Maria Elisa Mäder, eds, Revoluções de independências e nacionalismos nas Américas, Vol. One, Nova Granada, 2009, pp.21-108 and pp.109-69 respectively.

9 A good account of these early years is given by Jorge Myers, "A revolução de independência no Rio da Prata e as origens da nacionalidade argentina (1806-1825)', in Pamplona and Mäder, pp.69-130.

10 See Herbert S. Klein, A Concise History of Bolivia, New York, 2003, pp.89-118.

11 For Cuba, see the excellent work by Rafael Marquese, 'A escravidão caribenha entre dois atlânticos: Cuba nos quadros das independências americanas', in Pamplona and Mäder, Vol. Three, pp.237-321.

12 The opening of the ports to foreign commerce was responsible for the expansion of LusoBrazilian tropical staple products in Europe during the Napoleonic wars. Sugar, cotton, coffee, tobacco, rice, cocoa, spices, and animal hides, all had a guaranteed market in Europe while the Napoleonic wars were going on. Nevertheless, not all regions in the colony benefited with the presence of the Portuguese court. By contrast with the influx of wealth and the new dynamics of politics which attained the cities and main villages in the provinces of Rio, São Paulo and Minas, in the north-eastern areas, of lesser or diminishing importance for the Crown, pervasive old economic and social conflicts still endured. 


\section{Journal of New Zealand Studies}

13 An excellent work on the subject is João Paulo Pimenta. 'O Brasil e a 'experiência cisplatina' (1817-1828)', in JANCSÓ, István (Coord.), Independência: História e Historiografia, Sao Paulo, 2005, pp.755-89.

14 In the provisional government there were representatives of the Church, commerce, agriculture, Justice, and the Army. The Pernambuco revolutionaries adopted their own flag and drafted a Constitution, which granted them freedom of thought and religion.

15 See the works of Carlos Guilherme Motta, Nordeste 1817; estruturas e argumentos, Sao Paulo, 1972 and Evaldo Cabral de Mello, Rubro Veio: o imaginário da restauração pernambucana, Rio de Jeniero, 1997 (2nd ed), for an in-depth historiographical discussion on the topic of the Pernambuco Revolution.

16 Ilmar Rohloff de Mattos, 'Construtores e herdeiros. A trama dos interesses na construção da unidade política' in JANCSÓ, István (Coord.), Independência: História e Historiografia. Sao Paulo, 2005, pp.271-300.

17 The Regencies period began with King Pedro I's return to Portugal, in 1831, and ended with the so-called 'Golpe da Maioridade', on 23 July 1840, which declared the 15-yearold heir, Pedro II, an adult, and hence able to govern the country. The young emperor was crowned in July 1841 and his reign was to last until 1889.

18 A dense, well-executed study of these Saquarema years is offered by Ilmar Rohloff de Mattos, O Tempo Saquarema. Sao Paulo, 1987. 